\title{
The Genealogy of Civilization
}

\author{
Boštjan Marko Turk
}

\begin{abstract}
Civilization is a concept that ontologically defines the individual and the communities in which it develops. The most global civilization is the one that has emerged in the West. Civilization is not something static, but an organism that draws its roots from the distant past. In this sense, it is fundamental to answer the question of what are the constitutive elements that define Western civilization. This question only makes sense if it is asked in a historical perspective. In this direction the Freemasonry, A Very Short Introduction is a crucial one. It presents the analysis revealing how the history of freemasonry is related to the evolution of Western identity. It has to be read in the light of Niall Ferguson's monograph The West and the Rest. The present text does so. The book then brings to light the contribution of the brotherhood to the intellectual habitus of what is called the Judeo-Christian civilization, at the present time still predominant on the Planet.

The intellectual apparatus of the Freemasonry, A Very Short Introduction permits to elucidate the history of the masonic movement and its influence on events that seem unconnected and coincidental. Thus, this article tries to explain certain historical turning points in South-Eastern Europe, precisely in the light of the masonic alliances, in particular the case of the Illyrian Provinces and the first Slovenian poet, Valentin Vodnik, and secondly, what concerns the emergence of the Kingdom of Yugoslavia, which the author of the article defines as the result of the masonic strategy (the Grand Lodge of France and the Grand Orient of France).
\end{abstract}

Keywords: Andreas Önnerfors, freemasonry, Western Civilization, Southeast Europe, Illyrian Provinces, Valentin Vodnik, Charles Nodier, Napoleon, Kingdom of Yugoslavia 
A key question that arises in postmodernity, and especially in the 21st century, is that of civilizations. This question implies the question of the genesis, identity and persistence of Western civilization. The last one appears as a cultural factor. This includes arts, sciences, the use of technology, ethics and morals. Throughout its history, the culture of the West has co-shaped the social and political entities on the planet, with few exceptions. Western civilization is thus, in historical terms, the most global civilization we know. The question of its genealogy is therefore of primary importance, since it answers the question of its ontology and its viability.

Trying to understand what has shaped our cultural milieu, we cannot ignore the influence of the various associations of masonic orientation. Freemasonry: A Very Short Introduction is a work that synthetises the question of masonic groups and the genealogy of Western civilization. Namely, there is a thread running through the entire book that would be perceived by an attentive reader as the focal message. This is the analysis, which reveals how profound the history of Freemasonry is related to the evolution of Western identity. The book brings to light by way of explanation the contribution of the "brotherhood" to the intellectual, moral and political habitus of what is called the Judeo-Christian civilization, at present predominant on the Planet.

In fact, during the High Middle Ages, the Freemasons, while building secular and sacred buildings, were noted for the use of architectural elements that are indicative of the Western civilization. The starting point is Gothic architecture, which was built according to the principles of stonework combined with some specific knowledge, which was relayed to future generations. The architectural inspiration goes hand in hand with the idea of its transcendental foundation.

The Temple of Solomon, based on the Word (1 Kings 7:1-5), is crystallized in the syntax of the "Word of the Master". It constitutes the spiritual basis of the thought that shapes the architecture of the buildings. The hand that chisels the stone is in harmony with both. There is also the narrator who transmits knowledge. In the absence of print, this skill is crucial. One of the roots of modern pedagogics was born with the buildings that pierced the sky for the first time since the time of the pharaohs.

Another important feature of medieval craft guilds was that, in a time of widespread illiteracy and an absence of printed books, practical and applied know-how was orally transmitted and treated as privileged insider knowledge, constituting the secrets of a trade. Medieval society was organised into strict hierarchies and thus knowledge within the guilds was transferred vertically from master to journeyman to apprentice. The craft guild was a professional, social and religious fraternity, as well as representing a community of knowledge. (Önnerfors 38) 
The two elements of civilization, the sense of the divine, transmitted through speech, and the dissemination of knowledge coincide in the focal intentions of the first brothers.

Implicitly the book Freemasonry: A Very Short Introduction is the revelation that the communities of the masonic guilds presupposed the necessary use of skills which, in later centuries, helped to articulate Western civilization in such a way that it became the dominant model of the world. In this sense, another source can be drawn upon. This is Civilization, The West and the Rest. (Ferguson 2011) It offers an interesting parallel:

In 1500 the future imperial powers of Europe accounted for about 10 per cent of the world's land surface and at most 16 per cent of its population. By 1913, eleven Western empires controlled nearly three-fifths of all territory and population and more than three-quarters (a staggering 79 per cent) of global economic output. (Ferguson 5)

This phenomenon can be explained by the introduction of methodological elements that other civilizations did not know. The West in the morphological sense is not different from China, India, Turkey and other similar great empires. The difference is a matter of methodology: competitiveness, the scientific method, the ethics (of work), respect for the rule of law, medicine and consumerism are the six elements that Niall Ferguson calls the "killerapps", by analogy with software. We consider that only the first four are crucial: the other two are either embedded in them (consumerism) or came later and are derived from the first four, being created as a result. ${ }^{1}$ If we take into account Niall Ferguson's analysis, we can see that the contribution of Freemasons, especially from the time when the industrial age began, is more than notable:

The scientific image of freemasonry gave it a central place in the Enlightenment ideas of the period. Freemasonry is saturated with key Enlightenment concepts such as progress, perfectibility, and cosmopolitanism. On an individual level, freemasonry aims to promote a morality of autonomy, responsibility for the self, and moral example. These ideas are heavily influenced by classical stoicism: attaining a strong control of the passions and a mastery of the emotions while facing personal fate and any unforeseen challenges. (Önnerfors 46)

The excerpt bears noteworthy similarities with Fergusons's apprehension of large issues that assured the triumph of the West. The Knowledge and its transfer within the group are essential to increase competitiveness. In addition, a positive attitude

1 See the case of medicine. 
towards science and its promotion is also of paramount importance. Freemasonry doesn't lack a spiritual platform that accompanies and gives meaning to the development of science. We have mentioned three of them. In addition to spirituality, we should indicate moral autonomy, which is the innate concept of the so-called rule of law in every human being. Besides: ethics is the punctum saliens of the fraternity. It is the irreducible common denominator of masonic orientation, defending and recommending the concepts of good behavior. It is not a philosophical belief, but a practice that exists only incarnated in action:

There is no coherent ideology or doctrine of freemasonry. Rather, the fraternity is characterized by a considerable conceptual inclusiveness promoting an ethics of action; that is, an ethics of application rather than theory. (34)

Furthermore, Niall Ferguson identifies Isaac Newton as one of the key figures in the expansion of the West. But he was more than just a scholar. Aristotle, Pythagoras, René Descartes, Blaise Pascal (and others) were scientists who explored both the spiritual and material worlds and had a widely developed sense of the transcendent. It was not until the 19 th century that science began to be separated from faith. In this sense, there are masonic temples dedicated to Newton; it cannot be said with certainty that he belonged to the masonic fraternity. But his views were similar to those of Freemasonry, which explains why so many ceremonial buildings have been dedicated to his name.

It is known, however, that Isaac Newton belonged to the Rosicrucian movement. It had a profound influence on his philosophical thinking. For this reason, he should have been close to Freemasonry, by logic:

Under the surface of Protestantism, mystical currents of religiosity emerged, such as Rosicrucianism, which radically individualized the spiritual and personal encounter with the divine and charged it with strong symbolism. One of the master themes of the period was the search for secret and revealed analogies and correspondences between microcosm and macrocosm, heaven and earth, visible and invisible, divine and human. (Önnerfors 43)

Like thinkers and scientists, Newton was open to the immaterial dimension of the visible world. Just as he was aware of the general correlation between "heaven and earth, visible and invisible, and divine and human", ${ }^{2}$ he was aware of the complexity of the universe in its true grandeur. Newton was a part of the era that saw the greatest expansion of science in the modern sense of the word. Freemasonry followed the same path:

2 Quotation supra. 
Modern freemasonry (which throughout this book will also be referred to as the 'brotherhood' or 'craft') became a global movement in the 18th century and its ideas have since created a considerable social, cultural, and political impact. Since its official inception in 1717, without any formal governing body, it spread throughout the world as a prominent feature of associational life. It became one of the largest non-governmental secular organizations. (8)

The architect of the universe is also the architect of the civilization. Science, religion and art are inseparable parts of the complex historical structure. The diachrony of creation is synchronously actualized. Their interaction constitutes the building blocks of civilization. As it reflects the meaning that transcends all experience, it can only be conceived on an a priori, transcendental text: consequently from one of the sacred books. Freemasonry: A Very Short Introduction cites the movement's essential bibliographical reference, its canonical fundus. More importantly, James Anderson's book is based on an older text, the Gothic Constitutions. ${ }^{3}$ At the beginning of Anderson's Constitutions is the argument that man's creation as the image of God is related to the major skills the origin of which is contemporary with man's:

Adam, our first Parent, created after the Image of God, the great Architect of the Universe, must have had the Liberal Sciences, particularly Geometry, written on his Heart; for even since the Fall, we find the Principles of it in the Hearts of his Offspring, and which, in process of time, have been drawn forth into a convenient Method of Propositions, by observing the Laws of Proportion taken Year of the World 1. 4003 before Christ from Mechanism: So that as the Mechanical Arts gave Occasion to the Learned to reduce the Elements of Geometry into Method, this noble Science thus reduced, is the Foundation of all those Arts, (particularly of Masonry and Architecture) and the Rule by which they are conducted and performed. (Anderson 7-8)

Canonical texts have the advantage of offering several levels of reading: in the case of the Bible, there are four levels of interpretation, which Augustine of Dacia describes as follows: "Littera gesta docet, quid credas allegoria, Moralis quid agas, quo tendas anagogia."

Mutatis mutandis, the myth of Solomon's Temple is based on the Word and on the tradition. It is one of the most eminent buildings in the Bible whose symbolism can be grasped at several layers of interpretation. And again: on a literal level the temple was built, demolished and then rebuilt. The challenge is all the greater because from the point of view of symbolic meaning the building is constantly under construction. To build the Temple is to establish the civilization, through

3 Cf: https://www.masoniclibrary.org.au/research/list-lectures/86-gothic-constitutions.html, retrieved May 10, 2021. 
the knowledge entrusted to man at the moment of creation. In this context, the field of symbolic interpretation is as wide as possible, since its point of reference is at the limit of the ineffable, it is what is expressed by a structure typical of $\mathrm{He}-$ brew: "Sanctum Sanctorum". (Önnerfors 72) Thus:

The art of building, architecture, and geometry are all represented as exemplifying divine power and interference in human conditions exercised by the 'Great Architect of the Universe' (GAOTU). All important buildings mentioned in the Bible or known to the editor through classical literature and existent historical remains are linked to the science of masonry. Construction and re-construction are used as powerful metaphors, not as an abstract philosophy, but as an ethics of action in the service of humanity. Geometry and architecture occupy a civilizing function as expressions of divine order, providing a potential pattern 'for all nations' to follow and disseminate to distant cultures as far as Africa or India. (49-50)

In this sense, Freemasons present themselves as one of the builders of Western civilization. The history of the movement begins with the text of civilization, the Bible (the creation of Adam, Genesis 3). This is the transition from the transcendent to the rescendent order: it was realized once and for all. The mandate of the movement was born at this precious moment. The Constitutions of James Anderson provide the proof of this by placing the movement at the very heart of Judeo-Christian civilization.

But what is the civilization? We are aware of the arbitrary nature of the choice: however, the most academically noteworthy opinions in this regard were given by Paul Valéry (Valéry 1960) and André Malraux. (Malraux 1971) For the purpose of this discussion, we would rather quote Michel Onfray: his thought seems closer to the present moment: "Civilization is everything that crystallizes around a fiction that is itself rooted in a spiritual text. It is sacred, transcendent: it can be the Talmud, the Koran, the New Testament or the Bhagavat-Gita. There is no civilization without religion, which is its constitutive factor." ${ }^{4}$

The civilization cannot survive without the transmission of the genealogy, based on a sacred text: this task has been entrusted to the masonic movement in primis.

In Constitutions, genealogy is placed at the heart of the matter. It is the supreme modus operandi of the guild:

Freemasonry claims to possess privileged secrets and to transmit them internally. According to the narrative of The Constitutions, knowledge (transcending that of the average person) has been handed down via an uninterrupted chain of initiates

4 Onfray, Michel - LGL - Michel Onfray présente son nouveau livre : Décadence. Youtube. January 21, 2017. 
from biblical times. These initiates have each then had to endure pressure both externally from others in their society and internally from their own human need to communicate with others and share these secrets. (Önnerfors 57)

Evoking the ancient masonic texts, the Freemasonry: A Very Short Introduction exploits the apparatus of analogy to open it up to the very sources of masonic tradition and identity, sources synonymous with the first paragraph of Anderson's work, cited above:

Anderson's mythological account of freemasonry establishes a grandiose genealogy throughout the entire spectrum of intellectual history, encompassing the secular, Christian, and pagan. Thus, he constructs a narrative in which freemasonry is in possession of eternal ancient wisdom and uncorrupted knowledge of religion ('philosophia perennis' or 'prisca theologia'), handed down by generations of sage men united over the centuries and millennia in a privileged chain of initiates from almost every important religious and philosophical tradition. (51)

If this transmission is cut off, the civilization begins to collapse. Assuming that the genealogy is no longer in place; that the transmission of knowledge, skills and secret protocols is lacking, we enter the zone that represents the negation of the civilization as it has developed from the initial moment. Michel Onfray notes in this regard:

As soon as we cease to have the memory of our ancestors, as soon as we no longer know how to recount our genealogy, as soon as we are lost as to what made us or constituted us, civilization sinks. We no longer care about the history we no longer care about the past. In this hatred of the past, in this impossible present and in the configuration of a future for which we don't know what it will lead to, we are in the situation of a civilization that is collapsing. ${ }^{5}$

This would lead to a logical conclusion which can be uttered as a syllogism. We shall formulate it in the form of a question. If Freemasons have been a constitutive element of the civilization since its beginning, will the end of civilization herald the end of freemasonry? The significance of Freemasonry: A Very Short Introduction lies in the fact that it indicates the genealogy of the movement and, in this way, implicitly warns of the dangers facing the movement if this genealogy is ever lost.

Freemasonry - A Very Short Introduction not only raises general issues, but also addresses more specific ones. The book provides a framework for understanding cultural-political developments in countries that were not part of the European

5 Onfray, Michel - Interdit d'inerdire - Le Naufrage de notre civilisation. Youtube. March 3, 2021. 
alliance. The entry into modernity, through the Enlightenment, is an essential step, especially from the point of view of peoples who were still searching for their identity. Le Compte-rendu de la Loge serbo-française Général Peigné, written for the fiftieth anniversary of Yugoslav freemasonry, mentions the first Slovenian poet, Valentin Vodnik, among the Freemasons of this region. Thus, "Among the Slovenes, let us revive the memory of $B .{ }^{6}$ Valentin Vodnik, the great poet of the Illyrian period, so that the Slovenes understand the decisive role played by French freemasonry in the resurrection of their nation." (Spalaikovitch 17$)^{7}$ Until now, Valentin Vodnik's membership in freemasonry has been questioned, if not denied. ${ }^{8}$ His case is revealing in the sense of the coincidence of two characteristics that Fremasonry: A Very Short Introduction highlights as essential features of the movement. Firstly, Vodnik's poetry is oriented towards peaceful contentment with oneself and the universe. It expresses self-confidence, the joy of living and working without concern for major social, political or spiritual issues. Its values are Epicurean, happiness is within reach, man is intrinsically content with himself. In this sense, the title of his most important poem is The Satisfied Carniolan. ${ }^{9}$ The poet's worldview can be explained by the following quotation:

However, there is also an epicurean element, with the philosophical terms of 'felicity' and 'happiness' (derived from the Greek concept of 'Eudaimonia') occupying a prominent place in masonic ideology and symbolism, such as the omnipresent 'Temple of Felicity'. (Önnerfors 46)

To communicate his inner form to the whole nation, another moment was crucial for Vodnik: if the first moment was comparable, in terms of Roman mythology, to the goddess of happiness, Felicitas, the second moment bears the mark of a deity whose actions are unpredictable. Her name is Fortuna.* Valentin Vodnik was at his best during the time of the Illyrian provinces, established by Napoleon. They covered the territory of Slovenia, Istria, Kraina and Dalmatia. Again, Vodnik's engagement can be considered in accordance with the following:

At the turn of the century, Napoleon revived freemasonry in France and aligned the brotherhood closely with the ruling establishment. Thus, he created the ideological basis forging an elite in service to the universalist (and expansive) project of the French Republic and later Empire. This patriotic enthusiasm,

6 The letter $\mathrm{B}$ stands for brother.

7 All translations from French to English have been made by the author of the following article.

8 Cf: Binder, Dieter et al. The history and symbolism of the free masons. Celje: MD, 2008 and Resman, Gregor. Freemasonry and politics in Slovenia: a historical rewiev. Ljubljana: FDV, 2021.

9 Cf: https://sl.wikipedia.org/wiki/Zadovoljni_Kranjec, retrieved May 10, 2021. 
where humanist values of the Enlightenment were married with ideas of national independence and self-assertion, spilled over into a number of typically mid- and late-19th-century national freemasonries (...). (17-18)

Valentin Vodnik's intellectual activity, id est, that which influenced the genesis of Slovenian cultural identity, could emerge in the context of the revitalization of the Freemasonic movement under Napoleon. The peak of the poet's work can be traced back to the years 1809-1812, when the Austrian monarchy no longer interfered with Slovenian territory. The French authorities made it possible to use Slovene in public: Vodnik's native language became the language of education. Primary and secondary schools were established. Valentin Vodnik thanked Napoleon with the ode Illyria revived..$^{10}$ Illyria is personified as a woman who wakes up and tells Napoleon her glorious but forgotten history. The poet gleefully notes that Napoleon has revived an old heritage and that Illyria will become the heart of Europe. In this context, one should not overlook the fact that Charles Nodier, who edited the newspaper Le Télégraphe Officiel, was active in Ljubljana during the same period. Nodier, one of the most influential Frenchmen in the region, belonged to the Grand Orient de France. ${ }^{11}$ Le Télégraphe Officiel also published Illyria revived: "Nodier's note was printed next to the text, drawing attention to the merits of the poem itself, as well as to Vodník as an already renowned poet." (Kos 115)

After the restoration of the Austrian monarchy, Vodnik's situation deteriorated considerably. He was banned from public service. Until the second half of the 19th century, Slovene was removed from schools and offices and relegated to the status of an auxiliary language. The available sources do not yet allow us to classify Vodnik within the concrete masonic obedience. However, it is highly probable that he belonged to one of the French lodges established in Ljubljana during the Illyrian provinces. The extrait from the Compte-rendu shows that the Grand Lodge of France was well aware of Vodnik's activities: therefore, the most likely explanation is that Vodnik was a member of this Lodge or of one of its obediences.

The Apparatus of Freemasonry: A Very Short History can also be used to explain more important political changes that freemasonry triggered in the 19th century and the first half of the 20th century. We shall consider the following part:

At the outset of the 20th century, freemasonry changed from its original and dynamic 18th-century global network to an integrated phenomenon of elite sociability confined within individual national states and empires. Masonic universalism of the earlier period had changed into diverging and mutually

10 Cf: https://sl.wikisource.org/wiki/Ilirija_o\%C5\%BEivljena, retrieved May 10, 2021.

11 Cf: https://france3-regions.francetvinfo.fr/bourgogne-franche-comte/doubs/besancon/liberte-conscience-250-ans-franc-maconnerie-besancon-633078.html, retrieved May 10, 2021. 
exclusive national definitions of what constituted universal civilization. The British, French, and German empires all competed for their specific versions of world culture. (Önnerfors 25)

The text allows to understand the development of events in the southwestern part of the Balkan Peninsula during and after the Great War. It permits furthermore to place them in relation to the general development of the masonic paradigm. The less known documents could be used to apply the thesis to concrete historical material. It is about the transfer of the culture, identity and political will of France to the territory of the rising Kingdom of Yugoslavia. The Grand Master of the Grand Lodge of France, General Paul Peigné, played an essential role. When the Franco-Yugoslav Atelier bearing his name was founded in 1925, it was announced:

Our ideal in founding this Atelier was to strengthen our relations with the Balkan nations in order to fortify the state of peace, by bringing the Balkan peoples a little closer each day to the intellectual and moral centre which France represents in their eyes. (Spalaikovitch 6)

But the French went further: they wanted to transmit French culture to the $\mathrm{Yu}-$ goslav youth: they wanted to educate it in its own spirit, Freemasonry being one of the necessary elements of cultural and general identity. It is striking that the introduction to the world of French cultural identity and the introduction to freemasonry are almost synonymous:

We propose to recruit from among the Yugoslav university youth in Paris, wise minds who would complete their university education with a masonic education. The young students who are with us, even those who are more active in their studies, do not satisfy them enjoying our restaurants, cafés and bistros. When they return to their country, they have admired our monuments, our gardens, our capital, but the essence seemed to be out of grasp for them. We want them to be able to enter freemasonry, to follow our work, to get to know our masonic spirit and even to create family relationships among our masonic brothers. (6-7)

The goal was to become French at the same time as a freemason.

Over the course of the decades, representatives of the Grand Lodge of France and the Grand Orient have convincingly succeeded in recruiting Yugoslav youth. The document in question gives an account of the history of the masonic movement in Serbia. In this regard, the First Master of the Serbian-French Lodge, Venerable Gabriel Scellier, provides an analysis of Serbian freemasonry. He reveals the extent to which Freemasons are involved in the upper echelons of Serbian politics, science, art and literature: 
Almost all your scientists, writers and statesmen have belonged or still belong to freemasonry. In every government, several ministers are freemasons. This is also the case in the present Cabinet, chaired by the great statesman Pašić. Affection for freemasonry is one of the strong guarantees that Yugoslavia will follow the path of progress and strive to establish justice and peace, as well as the general welfare of the people, wherever they may be in the world. (6-7)

Aa soon as in the second half of the 19th century, Paris had serious ambitions in the southwestern Balkans. The path to realization passed through the Grand Lodge of France, and more precisely through a chance meeting, as Compte-rendu testifies:

In the tragic hours of the 1870-71 war Paul Peigné had under his direct orders a young officer, Prince Pierre Karađorđević, who had also graduated from SaintCyr. They have formed a lively friendship. This officer, thirty years later, was King of Serbia. (6-7)

When the royal house of Karađorđević came to power in Serbia (1904) and Peter became king, cooperation intensified. Peter Karađorđević turned Serbia away from Austria-Hungary and towards France. Freemasons played a key role in this, "orchestrating radical political changes." (Önnerfors 122) At the end of the First World War, the Grand Lodge of France and the Grand Orient supported the creation of a new state, the Kingdom of Yugoslavia, with Peter Karađorđević becoming its monarch. This completely transformed political relations in South Eastern Europe.

Referring to the Resolution (Lebey 1917) passed by the Congress of Freemasons of the Allied Countries between 28th and 30th June 1917, based on Wilson's theses on the self-determination of peoples, the two Lodges prepared a special document for the Paris Peace Conference (1919), demanding that the Conference establishes a State of Serbs, Croats and Slovenes. (Peigné 1919) They have also drawn borders on the map. The first proposal was respected, the second one, especially in the southwest of the new state, was not.

The state survived until the Second World War. It was during the reign of King Peter and his successor, Alexander, that the Kingdom of Yugoslavia made significant cultural and economic progress. It was a step towards civilization: Serbia, the backbone of the Kingdom, was irreversibly transformed. From a rural Eyalet integrated into the declining Ottoman Empire, it became a power that, as part of the Entente, successfully confronted the Austro-Hungarian monarchy in 1914-1918. All this would not have been possible if the French Republic had not invested Serbia (the Yugoslav Kingdom) with the civilizational achievements, synonymous with the cultural and economic infrastructure. As the historical documents reveal, the role of freemasonry, and in particular of the Grand Lodge of France and the 
Grand Orient de France, was of fundamental importance.

Freemasonry - A Very Short Introduction is an effective tool for confronting the mortgage imposed to the movement, as it itself diagnoses it in the final chapter:

From the margins of public debate, the issue of freemasonry has moved into mainstream media and governmental decision-making processes, where stereotyped images have been recycled, images that are likely to remain for the foreseeable future. (Önnerfors 123)

The book allows us to place the brotherhood in the precise historical contexts in which it has taken shape, in time, refuting the prejudices. Its main advantage is therefore providing a starting point for understanding the real nature of the movement and, above all, its contribution to the formation of civilization, in different historical contexts, however implausible they may seem. ${ }^{12}$

\section{BIBLIOGRAPHY}

Anderson, James. 1734. The Constitutions of the Free-Masons. Philadelphia: Masonica. Binder, Dieter et al. 2008. The history and symbolism of the free masons. Celje: MD. Ferguson, Niall. 2011. Civilization, The West and the Rest. London: Penguin. Kos, Janko. 1990. Valentin Vodnik. Ljubljana: PZ.

Lebey, André. 1917. Congress of the Masonic Societies of the Allied and Neutral Nations on June 28th, 29th and 30th, 1917: Grand Orient de France: Grande Loge de France. Paris: Mangeot

Malraux, André. 1971. Les Chênes quion abat. Paris: Gallimard.

Önnerfors, Andreas. 2017. Freemasonry - A Very Short Introduction. Oxford: Oxford University Press.

Peigné, Paul. 1919. Les revendications nationales des serbes, croates et slovènes présentées aux FF des pays alliés par les FF serbes, membres de la R.L. N288 Cosmos. Paris: Émancipatrice.

Resman, Gregor. 2021. Freemasonry and politics in Slovenia: a historical rewiev. Ljubljana: FDV.

Spalaikovitch, Miroslav. 1925. Compte-rendu de la Loge franco-yougoslave Général Peigné No 540 depuis sa fondation. Paris: L'Emancipatrice.

Valéry, Paul. 1960. "Regards sur le monde actuel et autres essais ", in Euvres II. Paris : Gallimard.

12 The case of Serbia and the Balkans at the end of 19th century, for example. 


\section{INTERNET SOURCES}

\section{Web pages}

https://france3-regions.francetvinfo.fr/bourgogne-franche-comte/doubs/besancon/ liberte-conscience-250-ans-franc-maconnerie-besancon-633078. html, retrieved May 10, 2021.

https://www.masoniclibrary.org.au/research/list-lectures/86-gothic-constitutions. html, retrieved May 10, 2021.

https://sl.wikisource.org/wiki/Ilirija_o\%C5\%BEivljena, retrieved May 10, 2021.

https://sl.wikipedia.org/wiki/Zadovoljni_Kranjec, retrieved May 10, 2021.

\section{Youtube}

Onfray, Michel - LGL - Michel Onfray presents his latest essay: "Decadence". Youtube. January 20, 2017.

Onfray, Michel - Interdit d'interdire - Le Naufrage de notre civilisation. Youtube. March 3, 2021.

Boštjan Marko Turk University of Ljubljana Bostjan-marko.turk@guest.arnes.si

\section{Genealogija civilizacije}

Ključno vprašanje, ki se zastavlja v postmoderni, še posebej pa v 21. stoletju, je vprašanje soočenja civilizacij. To vprašanje nujno implicira vprašanje o genezi, identiteti ter obstojnosti zahodne civilizacije. Ta se identificira kot kulturni dejavnik, v najširšem pomenu besede. Kultura se namreč na splošno nanaša na oblike človeške dejavnosti in simbolične strukture, ki dajejo taki aktivnosti pomen. V najširšem pomenu označuje izraz kultura vse produkte posameznika, skupine ali družbe inteligentnih bitij. Sem spadajo umetnost, znanost, raba tehnologij ter etika in morala. $\mathrm{V}$ tem smislu je kultura zahoda skozi zgodovino sooblikovala družbene in politične entitete na planetu, z redkimi izjemami. 
Zahodna civilizacija je tako v zgodovinskem smislu najbolj globalna civilizacija, kar jo poznamo. Vprašanje o njeni genealogiji je tako prvenstvenega pomena, saj odgovarja tudi na vprašanje o njeni ontologiji in o njenih sposobnostih preživetja.

Ključne besede: Andreas Önnerfors, prostozidarstvo, zahodna civilizacija, jugovzhodna Evropa, Ilirske province, Valentin Vodnik, Charles Nodier, Napoleon, Kraljevina Jugoslavija 